\title{
Ungovernability:
}

\section{The Unjustifiable Jurisdiction}

Juvenile and family courts in most states ${ }^{1}$ have jurisdiction over youths who have committed offenses (staying out late, disobeying parents, running away, truancy) illegal only for persons under a specified age, usually sixteen. ${ }^{2}$ Nationwide, at least one-quarter of all juvenile adjudications are for these offenses ${ }^{3}$ and studies suggest that forty to fifty percent of all incarcerated minors are charged with such noncriminal misbehavior. ${ }^{4}$

Statutes have long proscribed this misbehavior. ${ }^{5}$ Such statutes typically list these offenses in general terms ${ }^{6}$ as one of the many forms

1. See Comment, "Delinquent Child": A Legal Term Without Meaning, 21 BayLoR L. REv. 352, 369-71 (1969) (a useful survey of state laws in this area, including several pages of comparative tables); I. Solet, Report on State Laws Concerning Detention of Children, September 1973 (unpublished report of Yale Legis. Serv. in Yale Law Library).

2. New York, for instance, commences jurisdiction at birth and terminates it at 16 . N.Y. FAMILY Cr. ACT $\$ 712$ (b) (MCKinney Supp. 1973-74). Indiana terminates jurisdiction at 18. IND. CODE $\$ 31-5-7-4$ (1971).

3. See U.S. President's Comm'n on Law Enforcement and Administration of Justice, Task Force Report: Juvenile Delinquency and Youth Crime 4 (1967).

4. Klapmuts, Children's Rights: The Legal Rights of Minors in Conflict with Law or Social Custom, 4 CRIme AND Deline. LrT. 449, 470 (1972); cf. Downey, Why Children Are in Jail, 17 CHILDREN 21 (1970).

5. Such laws have been traced to early colonial concerns with the child's key role as a source of labor for the family economic unit. See Sidman, The Massachusetts Stubborn Child Law: Law and Order in the Home, 6 FAmILx L.Q. 33 (1971). One 1646 Massachusetts statute, for example, authorized the death penalty for a son's disobedience to his parents. Katz \& Schroeder, Disobeying a Father's Voice: A Comment on Commonwealth v. Brasher, 57 MAss. L.Q. 43 (1972).

6. Many of the statutes are aimed at behavior that is "ungovernable" or "incorrigible," N.Y. FAaily CT. ACr $\$ 712$ (b) (McKinney Supp. 1973-74), or at a youth "guilty of indecent or immoral conduct," IND. CODE $\$ 31-5-7-4(16)$ (1971), or at one who "deports himself so as to wilfully injure or endanger the morals or health of himself or others." Id. $\$ 31-5-7-4(17)$. Recent constitutional challenges have been made to such wording on the grounds that it is unconstitutionally vaguc. See Notc, Parens Patriae and Statutory Vagueness in the Juvenile Court, 82 YALE L.J. 745 (1973). The Supreme Court, without reaching the substantive issues, recently remanded such a challenge for reconsideration. Maillard v. Gonzalez, 42 U.S.L.W. 3583 (U.S., Apr. 16, 1974). In New York, the statute proscribing such behavior has survived a vagueness attack, at least in the state courts. See In re A., 31 N.Y.2d 83, 283 N.E.2d 432, 335 N.Y.S.2d 33 (1972); cf. Gesicki v. Oswald, 336 F. Supp. 371 (S.D.N.Y. 1971), aff'd mem., 406 U.S. 913 (1972). But see In re B., No. J.1365-73 (D.C. Super. Ct., June 14, 1973) (holding such a statute unconstitutionally vague). Even were such wording declared void for vagueness by the high court, however, states could still retain the ungovernability jurisdiction. A recently enacted Pennsylvania statute demonstrates the ease with which ungovernability jurisdiction apparently may be insulated from vagueness challenges:

"Delinquent act" means: . . (ii) a specific act or acts of habitual disobedience of the reasonable and lawful commands of his parent, guardian, or other custodian committed by a child who is ungovernable.

PA. Stat. Anv. tit. 11, \$50-102(2) (Supp. 1973-74). This Note questions the wisdom, not the constitutionality, of such statutes. 
of "delinquent" activity. ${ }^{7}$ In the early 1960's, however, New York and California ${ }^{9}$ rewrote their juvenile laws to separate noncriminal from criminal offenders by creating a new noncriminal category. This change rested on the assumption that youths who engaged in such noncriminal misbehavior needed and could benefit from court involvement, ${ }^{10}$ and that this benefit could be greatly increased were the stigma ${ }^{11}$ of "delinquency" eliminated and additional services provided in connection with a new classification. ${ }^{12}$ The new creation thus represented a fresh affirmation of the juvenile court's traditional efforts at "salvation." 13 As one advocate wrote, "In this class of cases there is no need for judicial power, as in the case of crimes, in order to protect the community ... The goal is only to help the child . . . ."14

The term chosen for noncriminal juvenile offenders was "persons in need of supervision" (PINS). In the 12 years since its formulation, the New York PINS statute has spawned a host of related statutes protecting juveniles, variously termed MINS (minors otherwise in

7. In 1901 noncriminal misbehavior was added as an element of delinquency in the Illinois juvenile court act, the nation's first. Law of May 11, 1901, [1901] Ill. Laws 141, 142, amending Law of April 21, 1899, [1899] 1ll. Laws 131. However, "punishment for such crimes pre-dated the Act." Schultz, Book Review, 82 YALE L.J. 629, 632 (1973). For a discussion of 19th century juvenile law, see J. Hawes, Children in Urban SoCIETY (1971); R. Pickett, House of Refuge: Origins of Juvenile Reform in New York State 1815-1857 (1969); A. Platt, The Child Savers: The Invention of DelinQUENCY (1969).

8. See N.Y. FAMILY Cr. Act $\$ \$ 711-84$ (McKinney 1963).

9. See Cal. Welf. \& INST'NS Code $\$ 601$ (West 1966), as amended, Cal. Welf. \& INST'NS CODE $\$ 601$ (West 1972).

10. The need for special treatment for children who do not obey their parents is predicated upon the existence of a "competence differential" between adults and youths. Indeed, early reformers of the law's jurisdiction over juveniles assumed the "natural dependence of adolescents and created a special court to further it." A. PLATT, supra note 7 , at 176 .

11. Cf. note 116 infra.

12. See N.Y. JT. Legis. Comm. on Court Reorganization, RePort, pt. 2, at 7 (1962) [hereinafter cited as 1962 CoMm. REP.].

But the Association of the Bar of the City of New York expressed doubt "whether this change in labeling will have the intended beneficial effect:" N.Y.C. BAR Ass'N Special Comm. on the Reorganization of the Courts, Reports on the Family Court Act Proposed by the Joint Legislative Committee on Court Reorganiza. TION 23 (1962).

13. See, e.g., Commonwealth v. Fisher, 213 Pa. 48, 50, 62 A. 198, 199 (1905), the most frequently cited rejection of constitutional challenges to the establishment of a separate juvenile jurisdiction: "[The Act] is not for the punishment of offenders, but for the salvation of children . . " Cf. the classic theoretical statement of the goals of the juvenile court in Mack, The Juvenile Court, 23 HARv. L. REv. 104 (1909). Mack concludes, "[t] he problem for determination by the judge is not, Has this boy or girl committed a wrong, but What is he, how has he become what he is, and what had best be done in his interest and in the interest of the state to save him from a downward career." Id. at 119-20.

14. Dembitz, Ferment and Experiment in New York: Juvenile Cases in the New Family Court, 48 CoRnell L. Rev. 499, 506 (1963) [hereinafter cited as Dembitz]. 
need of supervision ${ }^{15}$ and CHINS (children in need of supervision). ${ }^{16}$ It continues to serve as a model for reform. ${ }^{17}$

The PINS statute gives the state jurisdiction over any person less than 16 years of age "who does not attend school in accord with the provisions of part one of article sixty-five of the education law or who is incorrigible, ungovernable, or habitually disobedient and beyond the lawful control of parent or other lawful authority."18 Though anyone may initiate PINS proceedings, ${ }^{19}$ PINS cases often involve a petition brought by school officials alleging truancy ${ }^{20}$ or, more frequently, an "ungovernability" petition brought by parents alleging some form of youthful disobedience in such matters as associates, hours, sexual activity, language, general behavior, and residence (running away). ${ }^{21}$ The discussion that follows will evaluate the present functioning of the "ungovernability" element in the New York PINS statute to determine whether it provides a less detrimental alternative than no court involvement at all for ungovernable youths. ${ }^{22}$

Case surveys and court observation ${ }^{23}$ demonstrate that, in fact, the

15. See, e.g., Ill. ANN. Srat. ch. 37, \$ 702-3 (Smith-Hurd 1972).

16. See, e.g., FLA. StAT. ANN. $\$ 39.01$ (10)(a) (Supp. 1973.74).

17. Massachusetts recently revised its laws to produce a procedure analogous to that of New York by creating a category called "child in need of services." Mass. ANN. LAws ch. 119, $\$ 21$ (9 Adv. Legis. Serv, ch. 1073, $\$ 3$ (1973). New Jersey followed a PINS model in creating the category of "juvenile in need of supervision." N.J. REv. STAT. ch. 306, $\$ 4$ (5 Sess. Law Serv. (1973).

18. N.Y. FAMILY CT. Act $\$ 712$ (b) (McKinney Supp. 1973-74).

19. N.Y. FAMILY CT. ACr \$ 733(a)-(d) (McKinney 1963).

20. School officials bring 25 percent of PINS petitions. ADMIN. BD. OF N.Y. JUD. CoNF., REPORT FOR JUDICIAL YEAR 1972-73, at 331 (1974) [hereinafter cited as JUD. CONF. REP.].

21. Parents or parental surrogates bring 59 percent of PINS petitions. Id. For purposes of this Note, "ungovernability" is defined to encompass all cases initiated by parents. As the term properly suggests, such cases are always initiated by a dispute over whether the wishes of parent or child are to govern the youth's behavior.

Unrelated individuals, police, and various institutions account for the remaining 16 percent of petitions.

22. This standard is similar to that suggested in J. Goldstein, A. Freud \& A. Solnit, BEYOND THE BEST INTERESTS OF THE CHILD 53-64 (1973) [hereinafter cited as GoLDSTEIN], that juvenile courts attempt to serve not the "best interests" of the child but rather to find the "least detrimental alternative" available. Such a standard would "serve to remind decisionmakers that their task is to salvage as much as possible out of an unsatisfactory situation .... [and] reduce the likelihood of their becoming enmeshed in the hope and magic associated with 'best' which often leads them into believing that they have greater power for doing 'good' than 'bad." Id. at 63. It is wise for policymakers as well as decisionmakers in this area to use such a standard; it serves as a reminder that a legislator deciding on the existence of ungovernability jurisdiction is weighing two alternatives, neither of which can be fully satisfactory.

23. The discussion of the current state of the ungovernability jurisdiction, unless otherwise noted, stems from a summer of personal observation and interviews by the authors and from a survey of some 265 PINS case histories (including 129 ungovernability cases) in New York and Rockland counties of New York State. In New York County a 10 percent random sample of 1972 PINS cases was selected; in Rockland County all 1972 PINS cases were examined. The two PINS samples are nearly identical in size. New York has a greater percentage of ungovernability cases than Rockland ( 69 percent to 33 percent) and thus makes a proportionately greater con- 
purpose of the ungovernability jurisdiction is being subverted in two ways. First, the court processes as ungovernable some youths who are in fact either "neglected" or "delinquent" in statutory terms and who should be processed under the provisions governing persons in those categories. Second, in ungovernability cases the family court allows itself to be used by angry parents to punish their children. Moreover, the ungovernability jurisdiction often fails to carry out its purpose: discerning and meeting the "needs" of a youth who is in conflict with an affectionate, nonneglecting parent.

These failures can be traced to judges' inability to exercise the jurisdiction's vast discretion over youths without extensive, if unwitting, abuse. Abolition of the jurisdiction would be a less detrimental alternative for the youths involved than any form of its continuation.

\section{Background: The Statute's Structure and Scope}

Approximately seven thousand ungovernability cases are processed each year in New York State. ${ }^{24}$ The youths alleged to be ungovern-

tribution of cases to the ungovernability sample. Totals reflect approximate proportions for the state as a whole. Because of the different sampling proportions in the two counties percentages rather than absolute numbers are the significant measures in the analysis presented in this Note. The two counties are similar on most measures. Significant differences are noted throughout. Where the actual number of cases in particular categories is small, numerical data are provided and caution is indicated in making generalizations.

Observations were carried out pursuant to an organized research strategy. The authors observed every stage of court and probation processing of cases, including intake interviews, courtroom activity, and discussions in a judge's chambers. Observations were recorded after the event and were later checked for accuracy in interviews. See Maccoby \& Maccoby, The Interview: A Tool of Social Science, 1 HandBook of Soc. Psych. 449 (G. Lindzey ed. 1954). Accuracy was also checked in further observations. See Becker, Problems of Inference and Proof in Participant Observations, 23 AM. Soc. REv. 652 (1958). Because of the nature of the observations and the need to preserve confidentiality, many conclusions in this Note can be documented only by reference to the authors' experience.

The authors wish to thank Family Court Administrative Judge Florence Kelley and Director of Probation John A. Wallace of New York County and Family Court Administrative Judge Robert J. Stolarik and Juvenile Probation Supervisor Michael Frenchak of Rockland County and their staffs for the records that were made available for our inspection and for the kind assistance that was extended to us. In addition, the authors wish to thank the Yale Law School for supporting computer analyses of our data and to express gratitude to the Institute of Judicial Administration-American Bar Association Juvenile Justice Standards Project, and its Director, J. Lawrence Schultz, who sponsored our work.

24. This figure includes all those cases which are brought to intake, including those adjusted there. See p. 1388 infra. Cases of the latter sort are considered in this Note because they too have substantial consequences for the youth's life: Time is occupied, behavior probed, and, frequently, the youth is led to accept "voluntary" counseling under the threat of being sent to court in the future.

The numerical estimate in the text is derived by adding to the figure of 8,113 PINS petitions brought in New York State in fiscal year 1973 (JUD. Conf. REP., supra note 20 , at 329) an estimated 5,400 cases adjusted at intake (based on an extrapolation from our finding that approximately 40 percent of PINS cases are adjusted, never petitioned and thus not counted in official statistics) to yield a total of about 13,500 cases. In our study, ungovernability cases represented at least 55 percent of these. 
able are overwhelmingly in midadolescence; sixty-eight percent are over 14 and 44 percent are over $15 .^{25}$ They are predominantly girls ${ }^{26}$ and a majority are nonwhite. ${ }^{27}$ Many of these youths have been brought to court before. ${ }^{28}$ Their families are frequently broken, ${ }^{29}$ large, ${ }^{30}$ and poor..$^{31}$

The parental complainant ${ }^{32}$ initiates an ungovernability case by presenting various allegations of juvenile misbehavior ${ }^{33}$ to a member

25. The percentages of cases in the sample increase with the age of the youths involved. Only 5 percent of the cases involve youths under eleven, 9 percent involve youths eleven to thirteen, 19 percent involve youths thirteen to fourteen, and 24 percent involve youths fourteen to fifteen, and as noted in the text, 44 percent are over fifteen.

26. Girls constitute 62 percent of cases. The girls tend to be older than the boys. Several youths over sixteen were brought to court; all were female.

27. Black youths are involved in 40 percent of the cases; white youths in 31 percent and Hispanic youths in 28 percent. Thirty-five of the 44 black cases (and all of the Hispanic cases) occurred in New York, while 29 of the 34 cases involving whites occurred in Rockland. Information on race was not available in twenty cases.

28. Thirty-two percent have some previous court contact including, at a minimum, official contact with the court's Intake Unit. Of these, 18 percent had previous court contact on ungovernability matters. Thus nearly one in five has prior court involvement as an allegedly ungovernable youth.

29. Thirty-three percent live in family units where both parents are present. Fiftytwo percent live in homes where the mother is present but the father is absent; five percent live in homes where the father is present but the mother is absent; seven percent live with other relatives; two percent live with friends; and two percent live with guardians or foster parents. In 27 cases the youth lives with a single parental custodian whose household also includes some other adults. In four cases grandparents are present, in 19 cases a stepfather or paramour lives with the family, and in four cases a stepmother or girlfriend lives with the family.

30. The average number of siblings in the household where the youth lives is three. When the youth and an average of 1.5 adults (approximately 48 percent of youths live in a one adult household and 52 percent in a two adult household) are added to this total, the average size of households for youths charged with ungovernability is 5.5 persons. Siblings in such families have a high level of court contact. In 53 percent of the cases there was previous family court involvement on juvenile matters (the actual figure is probably higher for total family court involvement, since many of the parents have been involved in support and other adult cases over which the family court has jurisdiction).

31. The average family income is $\$ \mathbf{5}, 357$. Thirty-six percent of these families receive welfare payments. Whites are clearly wealthier; 83 percent of whites for whom income figures are recorded have family incomes over $\$ 5,000$, while 60 percent of blacks and 53 percent of Hispanics have incomes greater than this amount. None of the whites, 43 percent of the blacks and 61 percent of the Hispanics receive welfare payments. These figures are derived primarily from New York County, since income data is largely unavailable in Rockland County. The existing data from Rockland County indicates that the average family income in ungovernability cases is higher there than in New York.

32. Mothers are complainants in 75 percent of ungovernability cases, fathers in 16 percent, and parental surrogates (usually other relatives) in 9 percent.

33. See col. I of Appendix A infra for the percentage (and number) of cases in which the complainant makes different allegations at intake. Short runaway, defined as a runaway in which the youth is absent for less than a week (in contrast to long runaways when the youth is absent for more than one week), is the most frequent allegation; it appears in just over half of the cases. The next most frequent is refusal to obey, appearing in 47 percent of cases. Truancy, staying out later than the parents desire, and having companions whom parents find objectionable (the last category includes both undesirable companion cases in general and cases in which specific objection is made to a girl's boyfriend) are all of major concern, for they appear in more than one-third of all cases. Allegations which were not categorized (classified as "other" in the sample) appear frequently and include such matters as 
of the intake unit of the probation department located in the court building. ${ }^{34}$ An effort at voluntary ${ }^{35}$ adjustment follows if it appears that the court would have jurisdiction. ${ }^{36}$ This "intake procedure" is intended to "sift out cases not requiring judicial action." ${ }^{37}$ Some 46 percent of ungovernability cases are so adjusted, while the remaining 54 percent are referred on to court..$^{38}$

Formal court action is inaugurated at this time when the parent ${ }^{39}$ files a petition ${ }^{40}$ setting forth the allegations ${ }^{41}$ of the youth's mis-

refusing to bathe regularly, having an abortion against parental wishes, sleeping all day, refusing to do household chores, being selfish and self-centered, banging a door in reaction to a parental command, wanting to get married, attempting suicide, and being an "invertebrate [sic] liar."

Some 36 percent of cases include explicit allegations of behavior that would be criminal (a felony, misdemeanor, or violation) if committed by an adult; especially notable is the high percentage of allegations of drug usage. Explicit allegations of sexual misbehavior appear in 21 percent of cases, mostly against girls.

34. The Family Coutt Act does not specifically create intake units. The act permits "rules of court" to authorize the probation department to carry out the intake and adjustment procedure. N.Y. FAMILY C.T. ACT $\$ 734$ (McKinney 1963). The probation departments themselves have established structurally separate units to carry out this task.

35. The informal adjustment procedure is designed to be voluntary in that probation's screening "may not prevent any person who wishes to file a petition ... from having access to the court." Id. $\$ 734(\mathrm{~b})$.

Some commentators on the New York Family Court Act have questioned whether it is appropriate to permit insistent complainants to begin a formal action over the objection of the intake officer. Judge Dembitz notes that "some of the juvenile court acts have dispensed with this assurance of access to judicial process." See Dembitz, supra note 14, at 515 .

36. Adjustment efforts can only extend for an initial period of two months, how. ever, and then may be extended an additional thirty days only with the judge's permission. N.Y. FAMILY Cr. Acr $\$ 734$ (c) (McKinney 1963). Information gained therein may not be used at adjudication. Id. $\$ 735$.

37. Id. \$ 734, Comm. Comments.

38. Youths referred to court tend to be older; only 38 percent of adjusted youths are over fifteen in contrast to 48 percent of youths referred to court. Males are more likely to be referred to court; 59 percent of boys are referred to court, while only 51 percent of girls are so referred. By race, blacks are referred to court significantly more ( 64 percent of all cases) than whites or Hispanics ( 53 percent and 52 percent respectively). Youths who live with both parents are referred less frequently (48 percent of all cases) than youths who live with one parent or with parental surrogates (56 percent). See col. 2 of Appendix A for the percentages of youths who are charged with each allegation and who are referred to court.

39. The petition complainants are represented in the following percentages: mothers, 75 percent; fathers, 13 percent; other relatives, 12 percent.

40. N.Y. FAMILY CT. ACT $\$ 732$ (McKinney 1963).

41. See col. 3 of Appendix A infra for the percentage (and number) of cases in which typical allegations appear. The following allegations occur disproportionately often among older youths: Sixty-nine percent of all short runaway allegations concern youths over fourteen; 88 percent of long runaway allegations concern youths over fifteen. Eighty-nine percent of cases in which parents allege that the youth is associating with objectionable companions involve youths over fourteen and 67 percent of these cases involve youths over fifteen. Seventy-five percent of cases in which parents allege malicious mischief concern youths over fifteen. Likewise $7 \mathrm{I}$ percent of all assault allegations are against youths over fifteen; eighty eight percent of drug possession allegations are against youths over fourteen and 75 percent are against youths over fifteen; one hundred percent of the robbery allegations are against youths over fourteen; seventy-eight percent of the "other" allegations are against youths over fourteen and 56 percent concern youths over fifteen; and 100 percent of the allegations that a girl spent the night with a boy are against girls who are over fifteen. 
behavior. ${ }^{42}$ The respondent youth is then assigned a lawyer called a "law guardian." 43

There follow a number of preliminary hearings at which warrants may be issued, ${ }^{44}$ or detention may be ordered ${ }^{45}$ in secure facilities or nonsecure shelters. ${ }^{48}$ Barring a withdrawal or dismissal at this point, ${ }^{47}$ final decisions are reached by a bifurcated procedure. ${ }^{48}$ First there is an adjudicatory hearing ${ }^{49}$ where the allegedly ungovernable juvenile may either admit guilt or have a full trial, ${ }^{50}$ at which the

By sex, girls receive a notably higher proportion of the following allegations than their 57 percent representation in the sample of petitions as a whole: truancy, 62 percent; short runaway, 74 percent; long runaway, 73 percent; bad companions, 73 percent; drug possession, 60 percent; alcohol use, 67 percent; undesirable boyfriend, 100 percent; prostitution, 100 percent; promiscuity, 100 percent; cohabiting, 100 percent; spending the night with a boy, 100 percent; general sex innuendo, 100 percent. Boys strongly predominate (64 percent) in criminal allegations (which cluster in the older age groups; 50 percent are against youths over 15$)$ and in allegations of verbal misbehavior (71 percent).

42. A proper petition must allege three things: (a) that "the respondent is incorrigible, ungovernable, or habitually disobedient and beyond the lawful control of his parents, guardian or lawful custodian"; these must be substantiated by the specification of "the acts on which the allegations are based and the time and place they allegedly occurred"; (b) that the respondent was under 16 years of age; and (c) that the respondent requires "supervision or treatment." N.Y. FAMILY CT. ACT $\$ 732$ (a-c) (McKinney 1963). In practice the petitions are printed forms requiring only that the parent supply information about the respondent-youth, the complainant and the details of the allegation of "ungovernability." Intake officers or court clerks, not the complainants themselves, undertake the actual task of recording that information on the forms.

43. Id. $\$ 741$. This provision was necessary, the drafting committee noted, because "[t] he interests of the children and their parents are not always identical." 1962 Comm. REP., supra note 12 , at 3 .

44. N.Y. FAMILY CT. ACT $\$ 738$ (McKinney 1963). If the respondent and the person responsible for him do not appear after a summons, the court may issue a warrant directing that either or both be brought to court at a specified date and time. Id. $\S 725$. Warrants are issued in 38 percent of ungovernability cases. In one case, eight were issued.

45. Id. $\$ 724$. Detention is authorized in two instances: when there is a substantial probability either that the youth will not appear in court again or that he would be a danger to others. In 41 percent of the cases youths are detained.

46. N.Y. FaMILY CT. ACT \$ 720(a)(ii) (McKinney Supp. 1973-74) states that a secure facility is "characterized by physically restricting construction, hardware, and pro. cedures." A nonsecure facility is "characterized by the absence of physically restricting construction, hardware, and procedures." Id. $\$ 720$ (a)(iii).

47. Some 59 percent of the cases are withdrawn or dismissed, though rates sig. nificantly differ in the two counties (73 percent in New York, in Rockland only 29 percent). Cases may also, of course, be dismissed after an adjudication.

48. Cases average 78 days from intake to finding. In New York County the average is 68 days; in Rockland it is 87 days.

49. N.Y. FAMILY CT. ACT $\$ 742$ (McKinney Supp. 1973-74). This section defines an adjudicatory hearing as one "to determine whether the respondent did the acts alleged to show that he violated a law or is incorrigible, ungovernable or habitually disobedient and beyond the control of his parents, guardian or legal custodian."

50. Trials are extremely rare. Sixty-nine percent of the youths admit all the allegations, 24 percent admit some of them, and only 7 percent deny all allegations, forcing a trial. Yartial admissions are most frequent in New York, constituting 46 percent of all "pleas." Full admissions occur in 39 percent of New York cases and there are denials in 15 percent. In Rockland, by contrast, 94 percent of the cases involve full admissions, and 6 percent partial admissions; there were no denials. 
standard of proof is "beyond a reasonable doubt." 51 Subsequently,", the law mandates a "dispositional hearing ... to determine [by a preponderance of the evidence ${ }^{53}$ ] whether the respondent requires supervision or treatment." 54

Sixty-seven percent of the petitions are resolved in a "nonregulating" disposition, ${ }^{\mathbf{5} 5}$ withdrawal by the complaining parent, or dismissal by the judge. Under the general heading of "regulating" dispositions, ${ }^{\overline{5} \theta} 8$ percent of the juveniles receive "informal supervision" 57 or a suspended judgment, which may impose various terms and conditions on both parents and children for a period of one year, though a judge may grant another year's extension in "exceptional circumstances." 58 Another 10 percent are placed on probation. ${ }^{59}$ The terms of probation may include mandatory contact with a probation officer and a host of possible additional conditions, ${ }^{60}$ which may be imposed for a, period of one year (again a court may extend the period an-

51. In re Winship, 397 U.S. 358 (1970), extended the right to proof bcyond a reasonable doubt to minors charged with committing a crime. New York is one of the few states to have extended this right to ungovernable juveniles as well. In $r e$ E., 68 Misc. 2d 487, 327 N.Y.S.2d 84 (Fan. Ct. 197i). However, not much need be proved to meet the standard of "habitual" disobedicnce; there need only be proof that the juvenile was involved in more than "a single isolated incident." In re W., 28 N.Y.2d $589,590,268$ N.E.2d 642, 643, 319 N.Y.S.2d 845,846 (1971).

52. A confidential probation investigation of the youth's background and necds usually intervenes between adjudication and disposition. N.Y. FAMiLY Cr. ICr $\$ 746(\mathrm{~b})$ (McKinney Supp. 1973-74) provides in addition that such reports "may not be furnished to the court prior to the completion of a fact-finding hearing, but may be used in a dispositional hearing." Because of the time necessary for the completion of the required investigation and for probation to arrange a suitable disposition, dispositions occur on the average more than two months after a finding. While on the average 78 days elapse between intake and finding, on the alerage 143 days elapse between intake and disposition.

53. N.Y. FAMILY CT. ACT $\$ 745$ (McKinney 1963).

54. Id. $\$ 743$. The formal dispositional determination is scldom controscrtcd.

55. So termed because they involve no official regulation of the youth's subsequent behavior. The percentage of such dispositions is very low in Rockland, representing only 28 percent of the cases. In New York 83 percent of youths receive such dispositions.

56. So termed because each involves some sort of official supervision of the youth, though degrees thereof may range from infrequent probation supervision to total control in a training school.

57. In Rockland, 28 percent of youths receive such dispositions. In New York, no youths are so treated. Informal supervision is not really a disposition at all; it is a "freeze" of all action. After an admission, the court merely stays further procecdings and instructs the probation department to handle the case as if it were one involving informal probation, that is, as if the case had never come to court. Some judges resort to this device if they feel that a case should not be in court at all, but are nevertheless reluctant to dismiss for fear of embarrassing the intake officer.

58. - N.Y. FAMILY CT. AcT $\$ \$ 754(b), 755$; Rule 7.5 (McKinney 1963).

59. In Rockland, 22 percent of the youths are placed on probation; in New York, 5 percent of the youths are so placed.

60. See N.Y. CT. R. $\$ 2506.6$ (McKinney 1973) for a list of possible terms, among which are requirements that the youth obtain permission for any absence from the county for over two weeks, obtain a job, submit records of scholastic achievement or earnings and expenses, contribute to his own support, and refrain from driving a motor vehicle. 
other year). ${ }^{61}$ The remaining 15 percent ${ }^{62}$ receive some sort of "placement" for longer periods of up to eighteen months; extensions are possible at yearly intervals until the youth reaches age 18 (or, if the youth consents, until age 20). ${ }^{63}$ Youths may be placed with a relative, a private agency, a state camp, the Commissioner of Social Services, or-for those who are thought to need a structured, authoritarian environment-in a training school ${ }^{64}$ run by the State Division for Youth.

\section{The Failures}

\section{A. Jurisdictional Overreach: The Neglected and the Delinquent as Ungovernable}

In many of the thousands of cases processed each year, the purposes of the statute are subverted because the statute is misapplied to youths who are neglected or abused by their parents or are criminal offenders ("juvenile delinquents"). More suitable legal classifications and procedures are available for such youths.

In 37 percent of the cases, allegedly ungovernable youths are in fact neglected. ${ }^{05}$ When processed, these neglected youths are more likely

61. N.Y. FAMILY Cr. AcT $\$ \S 754(d), 757$ (McKinney 1963).

62. In Rockland, the figure is 22 percent, while in New York it is 12 percent.

63. N.Y. FAmLY Cr. ACT $\$ 754$ (c) (McKinney 1963); $\$ 756$ (McKinney Supp. 1973-74).

64. Originally only delinquents were to be allowed in training schools. Act of Apr. 24, 1962, ch. 686, $\$ 756$, [1962] 2 N.Y. Laws 2301 (McKinney). As a "temporary" measure, in 1963 some months after the Family Court Act was passed, an amendment to it permitted incarceration of PINS in the training schools for a year. Act of Apr. 26, 1963, ch. 809, $\S 10$, [1963] N.Y. Laws 1336 (McKinney), as amended, Act of Apr. 23, 1963, ch. 811, $\$$, [1963] N.Y. Laws 1339 (McKinney). The legislature enacted successive, temporary, one-year extensions. Act of Apr. 3, 1964, ch. 333, $\$ 1$, [1964] N.Y. Laws 515 (McKinney); Act of Apr. 26, 1965, ch. 126, \& 2, [1965] N.Y. Laws 190 (McKinney); Act of June 28, 1966, ch. 705, \$ 2, [I966] I N.Y. Laws 864 (McKinney). In 1968, it made this provision permanent. Act of June 22,1968 , ch. $874, \S \S 2-3$, [1968] 2 N.Y. Laws I784 (McKinney), as amended, Act of June 25, 1971, ch. 947, $\$ 10$, [1971] 2 N.Y. Laws 1524 (McKinney) (codified as amended at N.Y. FAMily Cr. Acr $\$$ 756(a) (McKinney Supp. 1973.74)). In 1973, the Court of Appeals handed down an unilluminating opinion prohibiting the incarceration of PINS in training schools for delinquents. In re C., 32 N.Y.2d 588, 300 N.E.2d 424,347 N.Y.S.2d 51 (1973). Now segregated PINS-only and delinquent-only training schools have been established. Office of Children's Serv. of the N.Y. Jud. Conf., The PINS Child, A Plethora of Problems, November 1973, at 77 (available at Office of Children's Serv. of the N.Y. Jud. Conf.) [hereinafter cited as OCS; Plethora].

65. A child was neglected for purposes of this Note if he could be processed under the statute's current neglect subsection, N.Y. FAMILY CT. Acr \$ 1012(f) (McKinney Supp. 1973-74), which reads as follows:

(f) "Neglected child" means a child less than eighteen years of age

(i) whose physical, mental or emotional condition has been impaired or is in imminent danger of becoming impaired as a result of the failure of his parent or other person legally responsible for his care to exercise a minimum degree of carc (A) in supplying the child with adequate food, clothing, shelter or education in 
to be referred to court and less likely to be adjusted than alleged ungovernables who are not neglected. ${ }^{66}$ Once in court, they are more likely to receive a finding. ${ }^{67}$ They also receive more regulating dispositions $^{08}$ and they receive a higher percentage of such highly regulating dispositions as training school and placement. ${ }^{69}$ Thus, not only are many youths who are in fact neglected processed as ungovernable, but the presence of parental neglect seems to encourage the court to maintain control over a youth and to subject him to its full regulating power. ${ }^{70}$

Court personnel readily admit that a high percentage of neglect cases are processed as ungovernable. ${ }^{11}$ Despite the option of treating

accordance with the provisions of part one of article sixty-five of the education law or medical, dental, optometrical or surgical care, though financially able to do so or offered financial or other reasonable means to do so; or

(B) in providing the child with proper supervision or guardianship, by unreasonably inflicting or allowing to be inflicted harm, or a substantial risk thereof, including the infliction of excessive corporal punishment; or by using a drug or drugs; or by using alcoholic beverages to the extent that he loses self-control of his actions; or by any other acts of a similarly serious nature requiring the aid of the court; or

(ii) who has been abandoned by his parents or other person legally responsible for his care.

Each ungovernability case was given an initial expansive coding for any indication of neglect or abuse. All indications of neglect or abuse in the court and probation records and agency and school reports were recorded in full.

The authors engaged in court observation of the processing of neglect cases. On the basis of the actual processing standard derived from those observations, the authors reviewed the information on each possible neglect case and re-rated it for the presence or absence of statutory neglect. This detailed coding in light of the statutory standard yielded far fewer neglect cases than had the initial designation. A reliability check of the comparability of the authors' codings of statutory neglect indicated agreement in more than 90 percent of all cases.

66. A recent study by the Office of Children's Services reached a similar conclusion. OCS; Plethora, supra note 64 , at 77 . In our survey, 45 percent of the petitions filed involved youths who could be denominated neglected, as compared with 37 percent of the youths brought to intake.

67. Thus, 50 percent of the juveniles who receive a "finding"-are formally adjudicated PINS-are in fact neglected, as compared with 45 percent of the youths against whom petitions are filed.

68. Sixty percent of the neglected youths in ungovernability proceedings receive nonregulating dispositions; 40 percent receive regulating dispositions. Seventy-one percent of nonneglected youths in ungovernability cases receive nonregulating dispositions; 29 percent receive regulating dispositions.

69. Neglected youths receive 100 percent of all training school dispositions and 60 percent of all placements.

70. In addition to those cases which would meet the requirements of statutory neglect, observation suggests that there are many cases in which the parents could be characterized as having "rejected" their children. Judges agrec. Interview with a judge of the N.Y. Family Ct., in New York City, Aug. 16, 1973. Such cases have not been included in the figures here.

71. Judges readily agree that "all PINS are neglected in some way." Interview with a judge of the N.Y. Family Ct., in New York City, Jan. 17, 1974. Others note that some of the PINS petitions before them "should have been . . neglect petition [s] years ago." Interview with a judge of the N.Y. Family Ct., in New York City, Aug. $9,1973$. 
such cases as neglects, ${ }^{72}$ they are handled as ungovernables because, observation suggests, judges in many cases do not want to face the delays and formalities that an accused parent and his or her lawyer will create in a neglect proceeding. ${ }^{33}$ There is also a reluctance in some cases to accuse an adult; it is simply easier to deal with a youth.

This practice of processing neglected youths as ungovernable may be criticized for two reasons. First, many of the private agencies which provide the best services available to the court are comparatively more likely to accept youths labeled neglected than those labeled PINS. ${ }^{74}$ Processing these youths as ungovernables limits their access to those services. Second, it is unfair to accuse a youth in connection with a matter in which fault, if it is to be placed, ${ }^{75}$ should be placed upon the adult. Penalizing the youth-even if only in such hidden ways as the greater stigma that attaches to being processed as ungovernable ${ }^{70}$-can only be detrimental to the youth's interests. ${ }^{77}$

Another group of allegedly ungovernable youths, perhaps fifteen to twenty percent, are accused of acts which would fall within the statutory definition of delinquency: ${ }^{78}$ acts (most often assault and

72. N.Y. FAMILY CT. Acr, § 716(b) (Mckinney 1963) authorizes substitution of a neglect for a PINS petition at any time upon the judge's own motion.

73. Such a conclusion is supported by similar observations on the part of law guardians in New York. Interview with Law Guardian Steven Eisenberg, in New York City, Aug. 30, 1973.

74. Telephone Interview with Polly Whitney, Social Worker, Juv. Rights Div. of the Legal Aid Soc'y, N.Y. Family Ct., Mar. 20, 1974. See Comm. on Mental Health SERVICES INSIDE AND OUTSIDE THE FAMILY CT. IN N.Y.C., Juvenile Justice Confounded: Pretensions aNd Realtries of Treatment Services 105 (1972): "Voluntary agencies have increasingly accepted more dependent and neglected children . . . " The report goes on to note that agency placement is most difficult for PINS when a child appears neglected and is in mid or late adolescence. All ungovernables are PINS, of course.

75. On this problem, Judge Dembitz's 1962 suggestion remains valid:

From the standpoint of statutory improvement, there perhaps should be a

device in the nature of a custody proceeding-blaming neither the child as

"ungovernable" or "delinquent" nor the parent, who may be exerting all his abilities, as "neglectful"- to determine whether the child needs custody other than parental.

Dembitz, supra note 14 , at 508 .

76. On stigma, see note 116 infra.

77. Nor can such a practice be defended by the assertion that many of these youths can be described as both "neglected" and "ungovernable," and can therefore justifiably be processed as either. In addition to the policy objections to such a course, legislative history strongly implies that, in overlap cases, the youth should be clas. sified as neglected. See, e.g., New York Family Cr. Act $\$ 739$ \& Comm. Comments (Mckinney 1963), which state that when a parent causes a youth to be detained by refusing to take him home, a neglect petition should be considered as a substitute for the PINS petition.

78. This figure is an aggregation of all allegations of acts which could possibly be considered crimes or violations if committed by an adult. Thirty-six percent of the allegations at intake and 41 percent of the allegations in petitions could be so characterized. However, in addition to major criminal allegations, these figures include a number of acts which would be insufficient to sustain a delinquency petition, e.g., a youth allegedly throwing a rock or snowball at a neighbor's house. Though there is no way to factor out such cases statistically, observation suggests that 15 or 20 percent is a fair estimate of the cases in which delinquency allegations were sufficiently substantial for a court to take cognizance. 
drug possession) which would be criminal if committed by an adult. ${ }^{70}$ The decision to process these potential delinquents as ungovernable frequently represents a conscious determination by court personnel to obtain dispositional power over a youth with the comparative ease afforded by the ungovernability jurisdiction. ${ }^{80}$ Such circumvention of the goals and processes of handling criminal offenders ${ }^{81}$ is unfair to the youths concerned and is a distortion of the purposes of the ungovernability jurisdiction.

\section{B. Angry Parents-Pressured Decisions}

Misapplication of the ungovernability statute occurs not only when it is extended to encompass delinquent or neglected youths. It occurs as well when the court, though confronting a conflict between a nonneglecting parent and a noncriminal youth, allows itself to be used by the parent to punish the child and fails to make an independent determination of the youth's condition.

Animosity between parent and child is common in ungovernability cases. A case is usually triggered by emotionally charged struggles between a parent and a rapidly maturing adolescent. A higher percentage of all parental complaints are made against those over 15 years old than against any other age group. ${ }^{82}$ Parental complaints frequently mention such matters as refusal to obey, the youth's friends, sexual activity, verbal behavior. Such issues often become a

79. N.Y. Famly CT. Acr \$ 712(a) (McKinney Supp. 1973-74). These statistics also include reports of harassment, which is currently a violation in New York but not currently subject to process under the delinquency laws.

80. Delinquent youths in New York are processed through the Family Court much as are PINS, but processing presents more obstacles for the court. Proof of delinquent behavior is more difficult to obtain, though in both cases proof must be beyond a reasonable doubt; in delinquency cases the petitioning party must prove that the youth at a specific time committed a specific criminal act. In ungovernability cases, the petitioning party need merely prove that the youth disobeyed his parents on some occasions. See note 51 supra. The latter typically involves fewer witnesses than are necessary in a delinquency proceeding and most if not all youths are guilty of same such disobedience in the course of growing up. This perhaps explains why only 7 percent of ungovernability cases are actually tried, while observation suggests that delinquency cases are tried four or five times as often (there is little or no plea bargaining in the Family Court).

The possibility of incarceration in delinquency-only training schools as a consequence of a delinquency proceeding (see note 64 supra) may also be a source of the vociferous opposition they evoke.

81. In one typical case a boy's mother filed a petition against him. The boy, it turned out, was an addict and the court mentioned the need for careful handling of this drug "pusher." Under questioning, the judge informed the authors that she was convinced that the child had violated penal statutes for selling heroin, "but if we have to prove this, it requires exact evidence that on such and such a date, at 6:02 p.m., he did such and such," a proof burden easily avoided under ungovernability jurisdiction. Interview with a judge of the N.Y. Family Ct., in New York City, July 24, 1973.

82. See p. 1387 \& note 25 supra. 
test of wills in which the question of "saving face" plays no small part. ${ }^{83}$

A parent who arrives at intake is often irate and hostile, ${ }^{84}$ a state that is aggravated by the admission of inadequacy which is implicit in a parent's seeking help from the court. ${ }^{85}$ Parents frequently recite a flood of allegations to the intake officer. ${ }^{86}$ While the officer may attempt to adjust matters and may even have a commendable success rate with the less insistent, ${ }^{87}$ often he simply acquiesces to a parental desire to see the youth in court. ${ }^{88}$

83. Allegations at intake include a lefusal to obey in 47 percent of the cases; late hours in 36 percent of the cases, staying out overnight in 19 percent of the cases, short runaways (less than one week) in 51 percent of the cases, long runaways (more than one week) in 13 percent of the cases, unacceptable speech in 21 percent of the cases, and undesirable friends in 14 percent of the cases. The other frequent allegation is truancy, which appears in 43 percent of cases. Strong emotional commitments on both sides often underlie such allegations. Other allegations which evidence controversies between parent and child but which fit none of these categories were represented in some 21 percent of the cases. See note 33 supra. More ungovernability cases are brought against girls than against boys. While 53 percent of all youths brought to intake are girls, 62 percent of all ungovernability cases at intake are girls. Parental complainants, it would appear, are more concerned about girls' behavior and set stricter standards for them. This is especially so in cases $(51$ percent of ungovernability cases involving girls) in which potential sexual involvements are alleged. Many judges cite as the typical ungovernability case a battle between mother and daughter over a "man." Interview with Administrative Judge Florence M. Kelley of the N.Y. Family Ct., in New York City, Aug. 8, 1973.

84. After conducting three weeks of observations and interviews, an assistant gathering information for the study reported: "All the I.O.'s [Intake Officers] spoken with feel that PINS mothers are despicable. There's no doubt that they either consciously or repressedly want to humiliate and punish their kids. It is most often the mothers who are messed up and need some supervision ...."

85. Interview with Mr. Guy DiCosola, Branch Chief, Manhatan Intake of the N.Y.C. Probation Dep't, in New York City, June 26, 1973.

86. Observation in Rockland County indicates that parents bring a "shopping list" of charges to intake. If they feel that the intake officer is not sufficiently persuaded of their desire to have the child brought to court, they will begin to recite additional allegations. Sometimes, if the intake officer decides from the initial description that the child needs the help of the court, the officer herself will vigorously question the parent to obtain any other allegations in order to bolster what may otherwise be a "weak petition." Much the same circumstances prevail in New York, where even more allegations are usually made in each case than is common in Rockland though intake officers are less inclined to bolster weak cases.

87. Some 46 percent of the cases are adjusted. The remaining 54 percent were sent to court. However, the youths in adjusted cases have not necessarily escaped all effects of court involvement. Those youths suffer a time loss and an intrusion into their privacy as the intake process is carried out and often (in 54 percent of all cases; 74 percent of the cases in New York, though only in 16 percent in Rockland) such youths attend "voluntary" counseling sessions under the threat of a return to court.

88. While statistics are not readily available, observation suggests that such a dynamic may be at work in perhaps one in five cases referred to court. It is reflected in the high percentages of "face-saving" allegations in cases referred to court. For instance, 88 percent of the cases in which the parent charges the child with disrespectful speech are sent to court. Sixty-two percent of the cases in which there are allegations of refusal to obey go to court. Sixty-four percent of the cases in which the parent, usually a mother, objects to the daughter's boyfriend and 80 percent of the cases in which the daughter is charged with being promiscuous go to court.

By contrast, only 50 percent of the cases in which the parent alleges arson or illegal entry go to court. Fifty-seven percent of the cases in which the parent charges the child with larceny go to court. See col. 2 of Appendix A infra. 
Once in court, parents often insist on immediate punishment for their children. The statute interposes no definitional barriers; as written it makes whatever the child has done unlawful as long as the parental order was lawful.s9 Parental passions-"He is such a liar, his mind is bad and he needs to be put away," said a parent in one caseare on occasion powerful enough to divert judges and other court personnel from questioning whether the youth may have been acting. justifiably or lawfully. The court typically responds according to the parent's wishes.

This response is, of course, difficult to measure statistically; it is often unwitting; court papers do not note "judge detained youth because parents so demanded." The degree to which the court functions in response to punitive parental desires can thus be statistically measured only obliquely, chiefly through examining detention decisions. This is the first major decision the court must make in any ungovernability case.${ }^{90}$ Additionally, a comparison can be made of the judgments and dispositions of youths allegedly ungovernable and those brought to court by schools and other nonfamilial complainants.

The Family Court Act authorizes detention only when the youth is likely to abscond or to commit a criminal act. ${ }^{91}$ The drafting committee noted in its comments on detention that "[i]f the court is concerned that the respondent will not have a suitable place to stay until the return date, it should consider whether a neglect petition should be filed."92 The statute clearly does not authorize detention when a parent refuses to take a child home. However, detention is frequently ordered for this reason, in explicit contravention of the statute: Eleven percent of all detentions are so granted, according to the written records, and observation suggests that the actual rate may be close to 50 percent. Moreover, when such punitive detention occurs, in two out of three cases the youth is placed in a prisonlike secure facility, a rate of secure detention as high as that for juveniles who the court fears will commit a criminal act. ${ }^{93}$

89. See p. 1385 supra.

90. At the close of the first hearing, the court must decide whether to parole or detain the youth. Otherwise, little business beyond the scheduling of the next appearance and the assignment of lawyers is transacted.

91. N.Y. FAMiLY C. ACT $\$ 739$ (ÁCKinney 1963).

92. Id., Comm. Comments.

93. Both secure and nonsecure detention facilities are woefully inadequate and possibly harmful for the youths in them. Many nonsecure shelters are tremendously overcrowded. See Note, Nondelinquent Children in New York: The Need for Alternative to Institutional Treatment, 8 Colum. J.L. \& Soc. Pross. 251, 266 (1972). A recent New York Assembly investigative committee report classified the shelter population as follows: "[T]wenty percent are mentally disturbed, 10 percent retarded, 3 percent actively homosexual, 30 percent seriously misbehaved and 10 percent physically handi- 
Thus in many cases a vengeful parent can bypass the intake officer, have a child brought to court, and compel detention by refusing to take him home. This may be all that the parent wants from the court and most parental petitions are withdrawn or dismissed without any continuing sanction. Even here, however, statistical evidence implies that bitterness lingers: There is a very low parental withdrawal rate (in contrast to dismissal by the judge) for many of the allegations that involve questions of "saving face," 94 particularly when a daughter is charged with sexual misbehavior, a highly sensitive and emotional matter for both parents and judges.95

\section{Ungovernability Jurisdiction: Failure in General}

Finally, a general survey of ungovernability processing reveals that the court's assessments are frequently inaccurate, its dispositions usually provide little effective treatment, and the long-term effects on a youth and his family are often negative. The inaccuracies in assessment are evident in the illogical patterns of decisions concerning which cases to adjust, whom to detain, which cases are serious enough to merit formal adjudication, and what dispositions are appropriate.

At intake, the seriousness of the allegations bears little relation to whether a case is adjusted or referred to court. ${ }^{96}$ Rather, the decision

capped." N.Y. Times, Dec. 15,1973 , at 35 , col. 8 . The committce substantiated reports that youths at the facility were confronted with "homosexual attacks, sexual solicitation, extortion and homicide," id., and depicted the facility "as a place from which youngsters easily sortie to commit muggings and return 'bedecked" in stolen finery and from which youths once left to perpetrate a rape and a murder." Id., Dec. I4, 1973 , at 51 , col. 1 .

As for secure facilities, a recent case mandating massive changes in programs found the following conditions: Youths were locked up as punishment even though the PINS youths had not harmed anyone; staffs were too small and inadequately trained; therc was no bona fide effort to treat the detained youths. Martarella v. Kelley, 349 F. Supp. 575 (S.D.N.Y. 1972). The officials in charge of both secure and nonsecure facilities in New York City adnit that the poor conditions in them harm the youths. N.Y. Times, Apr. 4, 1973, at 86, col. 1. For a lengthy discussion of facilitics and programs, sec id., Apr. 4, 1973, at 1 , col. 4 .

94. For instance parents withdrew no petitions in which they had alleged an undesirable boyfriend, though the court dismissed fully 60 percent of such cases. Only 24 percent of petitions alleging late hours were withdrawn, though 47 percent were dismissed; only 22 percent of the petitions alleging a bad companion were withdrawn, though 56 percent were dismissed; none of the petitions alleging verbal abuse were withdrawn, though 50 percent were dismissed; only 29 percent of the petitions alleging overnight absence were withdrawn, though 41 percent were dismissed.

95. In cases in which there were allegations of sexual misbehavior against a girl, parents withdrew only 13 percent of the petitioned cases while they withdrew 48 percent of those cases in which they made no such allegations. Cf. note 83 supra. 96. None of the cases alleging shoplifting, possession of a dangerous weapon, or burglary were referred to court. The charge of having a boyfriend objectionable to parents (64 percent referred to court) is treated more seriously than the charge of larceny (57 percent referred to court). Verbal abuse (100 percent referred to court) is treated more seriously than assault ( 73 percent referred to court). Refusal to obey 
to adjust an ungovernability case is principally a result of seemingly irrelevant secondary factors. ${ }^{97}$

Detention decisions in the course of court processing also demonstrate a lack of logic and an apparent disregard of the nature of the youth's problems and needs. Detention is more likely to occur in cases involving relatively minor allegations of ungovernable behavior than in cases involving more serious runaway and assault charges. ${ }^{98}$ The overwhelming majority of detained youths are sent to secure facilities irrespective of the seriousness of the alleged actions. ${ }^{\circ 9}$ And the reasons the court gives in support of its decision in selecting secure or nonsecure facilities suggest that considerations other than the problems and needs of the particular youth govern the decisionmaking at this stage of processing. ${ }^{100}$

Formal adjudications also fail to reflect the seriousness of the allegations. ${ }^{101}$ Sexual misbehavior is treated with greater concern than

(62 percent referred to court) and coming home late (59 percent referred to court) are treated more seriously than arson and illegal entry $(50$ percent of each referred to court). See col. 2 of Appendix A infra.

97. In New York, regression analysis reveals four factors which predict nearly half of the outcomes at intake. A petition is more likely to be referred to court if: (1) the juvenile is neglected; (2) he is relatively older; (3) grandparents live in the home (as contrasted to stepparents or paramours); (4) a single parent is the primary custodian.

In Rockland, 41 percent of intake decisions are explained by four factors. The likelihood of referral to court is increased if: (1) there is an allegation of criminal activity (interestingly, most of these criminal allegations are dropped from the actual petition once a case gets to court); (2) there are grandparents (as opposed to stepparents or paramours); (3) there is no allegation of short runaway; (4) there is no allegation of verbal abuse.

98. For example, in cases involving such minor allegations as verbal abuse and undesirable companions, the detention rates are 57 percent and 55 percent respectively. In cases involving more serious charges like assault, malicious mischief, and robbery, the detention rates are 14 percent, 25 percent, and zero percent, respectively. See col. 4 of Appendix A infra for the rate of detention for each allegation.

Regression analysis to determine factors that predict detention reveals that detention is more likely if: (1) there is no allegation of a long runaway; (2) stepparents or paramours live in the household; (3) there is an allegation of underage use of alcohol.

99. Of all ungovernable youths, 68 percent are sent to secure facilities and 32 percent are held in nonsecure facilities. Yet in New York County 57 percent of detainees for whom there are ultimately findings (presumably the more serious cases) are held in nonsecure facilities, while only 43 percent are held in secure facilities. The obverse of this anomalous pattern is of course also manifest for those for whom there are no findings: Sixty percent of these detained youths are held in secure facilities.

100. For example, when the official reason for detention is fear that the youth will abscond (see p. 1396 supra), 20 percent of the youths are detained in nonsecure, effectively open facilities, as are 33 percent of those detained as a danger to others. The latter percentage is the same as that of youths detained because their parents refuse to take them home. See p. 1396 supra. A regression analysis to determine factors affecting the choice of detention facility indicates that two factors explain 51 percent of the outcomes: Secure detention is more likely if (l) family income is low, and (2) the juvenile is neglected.

101. For instance, there was no adjudication in the one case involving robbery or in the four cases involving malicious mischief. One of 11 long runaway cases received a formal adjudication. In contrast, the adjudication rates for cases involving more minor allegations are high: short runaways, 52 percent; vile language, 60 percent; verbal abuse, 71 percent; undesirable boyfriend, 57 percent. See col. 5 of Appendix A infra. 
criminal acts. ${ }^{102}$ Moreover, a case that has advanced this far in the process is almost automatically adjudicated. ${ }^{103}$ Chance and endurance are thus critical. Adjudications are more likely if parents do not weary of court hearings, the youth does not outgrow the court's jurisdiction, and the law guardian does not persuade parent and child to accept a "voluntary" referral.

When the court eventually decides upon an "appropriate" disposition, ${ }^{104}$ the degree of regulation and service it mandates for the youth often seems an incongruously small return on the court's investment of time ${ }^{105}$ and labor, especially in light of the imposition upon the youth and his family. After lengthy processing, two-thirds of the cases are withdrawn or dismissed. ${ }^{106}$ Moreover, the disposition ultimately reached often appears to be inappropriate, given the allegations made and previous court involvement. ${ }^{107}$

Those who are subject to some type of regulating disposition are not thereby greatly benefitted. The primary disposition received by the majority of regulated youths is some form of generally ineffec-

102. Fifty percent of the cases in which there are allegations of sexual misbehavior are adjudicated; in contrast, only 36 percent of cases in which there are criminal allegations are adjudicated.

103. In 69 percent of cases, the youth admits the allegations against him in full; in 24 percent the youth admits the allegations against him in part. Thus, in only 7 percent of cases is there a denial of the allegations.

104. N.Y. FAMILY CT. AcT \$ 711(b) (MICKinney 1963).

105. The average time span from intake to disposition in an ungovernability case is 143 days.

106. Overall, 38 percent are withdrawn and 28 percent are dismissed.

107. A regression analysis exploring factors determinative of nonregulating and regulating dispositions indicates that the following factors explain 62 percent of the variance. A nonregulating disposition is more likely if: (1) family income is low; (2) the juvenile is charged with malicious mischief; (3) he is not charged with assault;

(4) a stepparent or paramour (rather than a grandparent) is also living in the household.

Several of the above factors that are predictive of nonregulating dispositions are also highly predictive of a youth's referral to court. See note 97 supra. Probation intake decisions and court dispositional decisions operate at irrational cross-purposes: Those factors at intake which are typically associated with a case sent to court are the same factors that characterize cases which are withdrawn or dismissed.

When the allegations in the petition are compared with the youth's disposition, it is evident that serious allegations do not receive proportionately serious dispositions, while less serious allegations receive far more regulating dispositions than they would appear to warrant. For example, all of the long runaway cases are withdrawn or dismissed, but only 61 percent of short runaways receive such nonregulating dis. positions. Eighty-six percent of the drug possession cases are withdrawn or dismissed; lesser percentages of cases involving undesirable companions, vile language, verbal abuse, staying out overnight, late hours, truancy, and refusal to obey also are allotted such nonregulating dispositions. Such cases are thus more closely regulated by the court than drug abuse. See Appendix B infra.

Such dispositions also scem illogical in light of previous court involvement. Overall, 65 percent of the youths whose cases are dismissed had previous court involvements (as do 30 percent of youths whose cases are withdrawn). On the other hand, none of those sent to training school or given probation had previous court contact and 60 percent of those placed in private agencies had no previous court contact. 
tive ${ }^{108}$ probation supervision. ${ }^{109}$ Of the more highly regulating dispositions, private agency placement, the most desired, is available primarily on a discriminatory basis; ${ }^{110}$ and its value once attained is open to question. ${ }^{111}$ Nonsecure state facilities, frequently dispensed as next-best alternatives, are likewise of dubious value. ${ }^{112}$ Training schools are a last resort. ${ }^{113}$

108. Probation usually involves merely perfunctory checkups. Probation departments are handicapped by limited manpower. New programs such as Alternatives to Detention and the Urban League's probation program in New York City have the unfortunate effect of draining the better probation officers from regular programs. Interview with Polly TVhitney, Social Worker, Juv. Rights Div. of the Legal Aid Soc'y, N.Y. Family Ct., in New York City, Aug. 29, 1973. Morcover, in other states, even new probation programs have proven unsuccessful. For instance, in a three year experimental program designed to improve the effectiveness of its parole (probation) program, the California Youth Authority attempted intensive rehabilitative supervision instead of the regular program. The result was negative: "Perhaps the most outstanding finding was that there were no significant differences between the experimental and regular parole (probation) programs in either project area on any of the parole performance criterion measures." Delinquency Control Project of the California Youth Authority, Summer Report, 1973, at iii. See Note, Persons in Need of Supervision: Is There a Constitutional Right to Treatment?, 39 BrookLY L. REv. 624, 638-39 (1973) [hereinafter cited as Right to Treatment].

109. Ten percent of the youths are given probation, 7 percent suspended judgment and 2 percent informal supervision. A total of 19 percent thus receive a disposition in which they are monitored by a probation officer.

110. Probation officers acknowledge it is more difficult to place minority youths in private agencies, even when both the probation officer and the judge feel that this disposition is most appropriate. Interview with Michael Frenchak, Supervisor of the Juv. Section of Probation, Rockland County Family Ct., June 26, 1973. Private agencies retain considerable veto power over the admission of ungovernable youths to their services. This veto is often exercised to separate youths on racial and religious grounds. In a recent suit brought by the Civil Liberties Union and the Legal Aid Society, seventy-seven children's services agencies in New York City and State joined in a consent decree in which the agencies acknowledged that "the religion-based system of placing children in need of help in New York City and State has the effect of discriminating against black Protestant youngsters." N.Y. Times, Jan. 6, 1974, $\$ 1$, at $68, \mathrm{col}$. 1. In a stipulation approved by U.S. District Judge Harold R. Tyler, Jr., the parties agreed that current practices had "the effect of depriving black Protestant and other children of necessary and proper services by denying them appropriate care." Id. See Right to Treatment, supra note 108, at 642-43.

111. Indeed many youths who are brought to court have already had unsuccessful involvements with such private agencies. A study of PINS youths (including ungovernables) found that 65 percent of the sample had had prior contacts with social agencies and a special bureau of the Board of Education, 28 percent had been in voluntary counseling, and 22 percent had attended a mental health clinic or had been treated at a psychiatric hospital before being brought to court on PINS charges. OCS; Plethora, supra note 64 , at 36 . Moreover, the Council of Voluntary Child Care Agencies reported last year with regard to such placements that "there is practically no accountability on effectiveness." N.Y. Times, Nov. 25, 1973, at 57, col. 1. The Council, through its assistant executive director, Mrs. King, noted that children "who remain in placement a long time tend to have a poor self-image, to be dependent, hostile, bitter toward their families and society, [and] have higher levels of anxiety about their future in the world." Id.

112. New York State Controller Arthur Levitt charged recently that resident re. habilitation programs operated by the Division For Youth for PINS and delinquents provided the youths with "spotty education, little or no psychiatric care and, in some instances, inadequate living accommodations." N.Y. Times, Dec. 2, 1973, § 1, at 49, col. 1; cf. Right to Treatment, supra note 108, at 644 .

113. Judges feel training schools provide inadequate rehabilitation and are reluctant to send youths to them. See N.Y. Times, Apr. 3, 1973, at 32, col. 5. Milton Luger, Director of the State's Division For Youth and responsible for the training schools, 
In the end most court processing is of limited utility. It effects little positive change for most youths, many of whom will soon .reappear at intake with the same complainant and similar allegations. ${ }^{114}$ In other instances, the dispositions serve only to generate further business for the court.115 And whatever the dispositional outcome its value is eroded by various long-term aftereffects. For example, the research literature on stigma has proven the extent to which juvenile court adjudications tend to alter the juvenile's image not only in the eyes of others, but also in his own eyes; his changed perception of himself as "tarnished" and less valued than others is accompanied in the long run by a loss of respect for the institutions of law and authority in general. ${ }^{116}$

admits they are "irrelevant" and that their staffs "don't know how to work effectively with kids." Id. See Right to Treatment, supra note 108, at 639-42. In an effort to avoid sending New York youths for whom private agency placements cannot be found to such institutions, courts often send them instead to the Commissioner of Social Services. They are then detained (see discussion of detention facilities at note 93 supra) for periods of several months while fresh attempts at placements with the same agencies are made for them. Interview with A.H. Gross, N.X. County Branch Chief (West) for Investigation and Supervision of the N.Y.C. Probation Department, in New York City, July 6, 1973. See Right to Treatment, supra note 108, at 643-44. Cf. OCS; Plethora, supra note 64, at 58-61.

114. In 33 percent of the cases, youths have subsequent court contacts. Seventeen percent of the youths have subsequent court contacts as ungovernables; of these, seven cases, 32 percent, involve the same complainant as in the original ungovernability case. Moreover, the pattern of allegations in these subsequent ungovernability cases resembles the pattern of the original intake ungovernable allegations: For example, 46 percent of the later petitions also allege short runaways, 14 percent also allege assault, and 9 percent also allege a variety of "other" charges.

115. Of cases which returned, 12 percent did so upon petitions brought by official personnel asking modification of placement or alleging violation of the terms of pro. bation. In Rockland, 67 percent of the recidivists were brought in on such petitions; 17 percent came from agencies asking placement modification and 50 percent from probation officers alleging violations in the terms of probation.

116. When the PINS jurisdiction was developed in 1962 it was hoped that little or no stigma would accrue to an adolescent because the societal diagnosis, as manifested in the PINS label, was that he should be "helped" and "saved." See p. 1384 supra. It was reasoned that since stigma is a result of a process by which society identifies and labels reprehensible behavior and attributes, when the attributes labeled are less reprehensible, there should be a lesser degree of stigmatization. This is likely to be true for adults. Adolescents, however, by reason of their state of psychological development, do not pay much attention to the degree of "reprehensibility" of the bad things they are accused of. If an adolescent is adjudicated "ungovernable" (in New York, a "PINS"), he does not care that he is less "bad" than a delinquent. Rather he focuses on the judgment that he is not normal, not as good as others of his age. Erik Erikson in detailing his theory of development has remarked of adolescent reasoning:

An adolescent feels that to be a little less of one means to be much more of the other-or, rather to be a little less of one means to be all of the other. If ... something that happens psychosocially marks him . . he may develop a deep fixation connected with a negative identity.

Dep't of HEW, Pub. No. 56, New Perspectives for Research on Juvenile DelinQUENCY 10 (H. Witmer and K. Kotinsky eds. 1956).

Another aspect of the stigma affixed by juvenile court involvement lies in society's discrimination against such youths in matters such as jobs. The Family Court Act contains an effort to ameliorate this problem by protecting records from "indis. criminate public inspection." Records may not be released without court permission. 
Furthermore, observations suggest that ungovernability proceedings increase an embattled parent's already heavy burden by emphasizing the parent as the only source of rationality and competence within the family unit; by presuming the child helpless and incompetent, the court process cuts off the strength and support which the child might bring to the family were he treated as a responsible and contributing member of it. Thus, rather than strengthening the parentchild relationship in the child's interest, ungovernability jurisdiction weakens the family and isolates the child-respondent from it.

\section{A Basic Flaw}

The frequent failures of the ungovernability jurisdiction stem from the inability of family court judges to exercise their wide discretion over youths without often serious misassessments. ${ }^{117}$ Unlike the problems of inadequate services and facilities which also plague the court, this problem is systemic and not susceptible to any simple solution. ${ }^{118}$

In ungovernability cases a judge is given problems far more delicate and complex and far less subject to judicial solution than those in most areas of law. ${ }^{119} \mathrm{He}$ must accurately assess a parent-child con-

N.Y. FAMILY Cr. ACT $\$ 766$ (McKinney 1963). In fact, however, records are frequently released to police, armed forces, potential employers, and others. Confidentiality is thus seriously undermined and prior juvenile court involvement continues to stigmatize youths in the wider society.

For a detailed analysis of stigmatization in the context of the juvenile court, see A. Mahoney, Youths in the Juvenile Justice System: Some Questions about Empirical Support for Labeling Theory, 1973 (Working Paper, ABA-IJA Juvenile Justice Standards Project).

117. Most judges and the Office of Children's Services of the State Judicial Conference insist to the contrary that the problems with the jurisdiction stem primarily from a lack of services and generally inadequate financial resources. Interview with Administrative Judge Florence Kelley of the N.Y. Family Ct., in New York City, Aug. 8, 1973; cf. OCS; Plethora, supra note 64.

118. It is important to remember that, while a vast inflow of funds would no doubt improve staffing and physical conditions at the various facilities which the court relies on, such improved conditions would not necessarily guarantec the effectiveness of the services. Sciencc is still unable to predict accurately what will cure the problems of youths enmeshed in complex parent-child conflicts. Hence, it is an open question whether even an inflow of funds would enable these institutions to surmount limitations of human insight so that the youths sent to them would leave in a state substantially less detrimental to their interests, see p. 1385 \& note 22 supra, than similar but "untreated" youths. Professor David Fanshel, Director of the Child Welfare Research Program, Columbia University School of Social Work, has conducted an cxtensive longitudinal study of the effects of child care institutions upon children. His results, still being analyzed, will provide valuable evidence of the value of institu. tionalization. Letter from David Fanshel to R.H. Andrews, Jr., Apr. 15, 1974, on file with the Yale Law Journal.

119. They are, for example, unlike those which typically occur between contracting parties or between a tortfeasor and victim in that they are of vastly greater duration, intimacy, complexity, and (frequently) emotional intensity. A judge is thus presented with a more multifaceted problem than in other areas of law (with the possible ex. ception of divorce law in some states; see Goldstein \& Gitter, On Abolition of Grounds for Divorce: A Model Statute and Commentary, 3 FAmily L.Q. 75 (1969)) when he is 
flict and determine what kind of "help" the child involved may need. To permit the judge to understand and cope with problems of such intricacy, the statute gives him vast discretion with respect to what information he is to consider relevant ${ }^{120}$ and it sets no standards for decisionmaking in order to avoid compromising this task. ${ }^{121}$

However, in a court process which by its nature exists to decide cases, the absence of standards leaves a void as to how decisions should be made. In some cases, fortunately, the process works as intended: Because of the latitude which he is allowed, the judge is able to assess accurately the youth and family before him. In many other cases, the judge in the absence of standards falls back, though often unwittingly and with the best intentions, upon personal feelings and predilections in making his decisions. He is, moreover, left vulnerable to inappropriate influences from court personnel and parents.

The ungovernability jurisdiction affords less protection against the intrusion of the judge's personal predilections than do other legal proceedings that consider narrower issues; ${ }^{1: 2}$ and because the persons dealt with are youths, the personal predilections of judges as adult decisionmakers are more likely to be subject to inaccuracies and misconceptions. Youths are often seen as less than full persons, ${ }^{123}$ whose problems judges and adults generally assume are easily understood ${ }^{124}$ and readily remedied. ${ }^{125}$ Judges are also more likely to universalize

told to assess and ameliorate the situation "in the child's best interests." $C$ f. GoldsterN, supra note 22, at 8: "[L] aw is incapable of effectively managing, except in a very gross sense, so delicate and complex a relationship as that between parent and child."

120. The discretion derives from the fact that anything more than "a single isolated incident" of disobedience will suffice for a finding that a juvenile is a PINS. See note 51 supra. The judge is given no standards as to what might constitute reasonable and lawful parental behavior or how dispositions should be matched with specific problems.

121. As Judge Dembitz noted in 1962:

It is the broad discretion in both phases of the proceeding-both in adjudicating whether the child is within the court's jurisdiction as well as in his dispositionwhich gives the judge an extraordinary and troubling degree of power over children who are before the court though they have not broken any law.

Dembitz, supra note 14 , at 508 .

122. The judge has less scope for the play of personal predilection in considering whether a particular youth did or did not rob a person at a certain time as alleged in a delinquency proceeding than in considering whether a youth in conflict with his parents should be adjudicated ungovernable.

123. Cf. GolDSTEIN, supra note 22, at 3.

124. The following diagnosis offered by a family court judge is instructive: "She thinks she's a pretty hot number; I'd be worried about leaving my kid with her in a room alone. She needs to get her mind off boys." In-chambers observation of a judge of the Rockland County Family Ct., June 26, 1973.

125. Said a judge of one mother-daughter conflict, "She's way too big for her pants and that's putting it nicely . . . [i] what she needs is a good spanking." Observation of a judge of the N.Y. Family Ct., in New York City, June 29, 1973. Since childhood and adolescence are universal human experiences, judges and probation officers may feel that they "know" a great deal about them and that they can "cure" whatever maladies arise. A parallel attitude is manifested toward marriage by judges in divorce cases. See Goldstein \& Gitter, supra note 119. 
unconsciously their own experiences and standards with juveniles than with adults; ${ }^{126}$ the consequence is a foreclosing of receptivity to the individual juvenile's particular social and personal circumstances. ${ }^{127}$ In addition, most judges, like other adults, possess an unconscious ambivalence toward youths. ${ }^{128}$

The intrusion of personal feelings and predilections is exemplified in the presumption by some judges that the youth must be the erring party if a family conflict exists ${ }^{129}$ because a child owes obedience to parents under all circumstances. This presumption is discernible in the language of the statute, which proscribes as ungovernable any juvenile behavior that contravenes a lawful parental command. ${ }^{130}$ Only certain favorable middle class characteristics-a high I.Q., ${ }^{131}$ diligence in keeping appointments, deference to judicial authoritycan lighten the burden of this presumption.

The absence of standards leaves the decisionmaking process in ungovernability cases vulnerable as well to the pressures of some adults who may not be fully devoted to the individual respondent's welfare. Such pressure may come in subtle form, as in the power exercised

126. Attitudes towards sexual activity are a prime example of this. A typical judicial comment on fourteen-ycar-old girls is that at that age girls "get some crazy ideas. They want to fool around with men, and that's sure as hell trouble." Interview with a judge of the N.Y. Family Ct., in New York City, July 27, 1973.

127. Thus, the authors witnessed a judge at an intake hearing who, after no more than a cursory consideration of the allegations and without any consideration of other factors in the case, told one girl:

I want you to grow up to be a fine young lady. But you must obey your mother-legally, morally, and in every other way she is your mother, and you must do what she tells you. Because if you go wrong, she's the first one who's blamed.

Statement of a judge of the N.Y. Family Ct., in New York City, Aug. 17, 1973.

128. See Goldsrein, supra note 22, at 106 .

129. Charged one judge upon paroling a girl in her first hearing:

I want you to promise me to obey your mother, to have perfect school attendance and not miss a day of school, to give up these people who are trying to lead you to do wrong, not to hang out in candy stores or tobacco shops or street corners where these people are, and to be in when your mother says: if it's 6:00 it's 6:00, if it's 7:00 it's 7:00, if it's 8:00 it's 8:00, but by 9:00 1 don't want to see you on the streets of this city except with your parents or with your clergyman or to get a doctor. Do you understand?

Yes.

Statement of a judge of the N.Y. Family Ct., in New York City, Aug. 17, 1973.

Another judge said that, even if he dismisses a case as unjustified (which happens very rarely), he gives the youth a stern talking to: "I want him to benefit from his exposure to the court." Conversation with a judge of the N.Y. Family Ct., in New York City, July 24, 1973.

130. See p. 1385 supra.

131. For instance, there is a clear trend in detention decisions; those not detained tend to have higher I.Q.'s. Data in New York makes it apparent that those with findings are overwhelmingly those with lower I.Q.'s; judges are willing to give a brighter youth a break on the theory that he "might really become something." And, finally, the more regulating dispositions go to those with lower I.Q.'s. 
by groups of court personnel, ${ }^{132}$ or in more blatant form, as in the influence angry parents have upon decisions. ${ }^{133}$ In either case, such pressure has greater impact than it would if adults instead of youths were the respondents.

\section{Abolition and Its Consequences}

Judicial processing of ungovernable youths has severe failings the causes of which are probably irremediable. It would be less detrimental for youths if they were dealt with, where appropriate, as delinquent or neglected, or indeed if they were not dealt with at all. The ungovernability jurisdiction should be abolished.

Were such a step taken, jurisdiction could of course be retained over those youths, now processed as ungovernable, who are in fact criminal or neglected. This step would afford delinquent youth the constitutional protections to which they are currently entitled..$^{134}$ It would also probably yield an increase in services for neglected youths. ${ }^{135}$

Jurisdiction over youths who resort to force against a parent would also not be lost. Indeed, such youths are now subject to adjudication as "family offenders" 136 just as adults are ${ }^{137}$ when they resort to physical force during a family controversy. Though this provision is little used because of the easy availability of the ungovernability

132. Both New York and Rockland observation indicates that one group of court personnel dominates the processing of a case and thereby strongly influences judges' decisions in accord with its own institutional and ideological biases. In Rockland, this group is the probation department. In the absence of "resident" attorneys (law guardians in Rockland are simply appointed members of the County bar), probation officers are able to control what information is amassed and what is presented both to the judge and to the law guardian representing the respondent.

In New York, law guardians (a group of young attorneys who are "resident" in the Court and are retained by the city from the Juvenile Rights Division of the Legal Aid Society) are the dominant force. They influence case outcomes by effective preemption of such tasks as gathering detailed information on the respondent juvenile prior to a finding and making postpetition pretrial conciliation attempts and also by their ability to manipulate influence factors in the judicial process, e.g., which judge hears which cases. Since their acknowledged preference is strongly against any PINS jurisdiction, far fewer cases in New York actually come to an adjudication than in Rockland (fewer than 25 percent in contrast to over 60 percent in Rockland). In both jurisdictions, therefore, the statutory model of the judge as central decisionmaker with unfettered access to impartial information is unrealized.

133. See pp. 1394-97 supra.

134. See pp. 1393-94 supra.

135. See p. 1393 supra.

136. N.Y. FAmILY CT. ACT $\$ 812$ (McKinney Supp. 1973-74).

137. The family court may now waive those accused of a family offense to the Criminal Court. Id. $\$ 816$. This provision presumably does not and would not apply to youths under sixteen; rather, youths would be subject to a delinquency petition should the court decide that the reconciliative aims of the family offense jurisdiction were inappropriate. 
jurisdiction, in the absence of that jurisdiction there is no reason why this provision could not be invoked whenever appropriate.

However, noncriminal, nonneglected youths simply brought to court for "help" in the wake of disagreements with their parents would not, of course, receive the court's help. Rather, family members would have to fall back upon their own personal resources and upon the range of community resources that often go underutilized ${ }^{138}$ in the rush to bring children to court.

There are, of course, a few youths who need help and who might not receive it from other sources. ${ }^{139}$ But it must be remembered that many of the ungovernability cases which come to court involve issues of passing rather than ultimate significance ${ }^{140}$ in the lives of youths

138. In Rockland County, for example, the Volunteer Counseling Service accepts referrals from the court on a "voluntary" basis of youths and their parents for counseling on family problems. Judges note, however, that parents seldom attend more than one counseling session before returning to the court, which they find better suited to their purposes. Interview with a judge of the N.Y. Family Ct., in New York City, Aug. 2, 1973 .

139. Indeed, it is widely believed that untreated ungovernables are almost certain to become delinquents. "PINS behavior, especially among boys, is seen as the harbinger of crime, demonstrating a proclivity for 'bad' behavior. . . . The detection of a "proclivity to bad behavior' is facilitated by the court's 'treatment process.'" Silver, The New York City Family Court: A Law Guardian's Overview, 18 CRIME \& DeLINQ. 93, 95 (1972). Though persistent, the view that the ungovernability jurisdiction serves as an accurate early warning system for apprehending children in an incipient "predelinquent" phase before they actually commit a delinquent act, and thus prevents them from committing such acts by providing court supervision and treatment, has largely been scientifically discredited.

Neither the predictive nor the preventive abilities of the jurisdiction bear up under critical scrutiny. First, there is no consensus as to what behavior is included in the category "predelinquent." Since a delinquent is a young person apprehended and convicted of a criminal act, the profile of delinquent category is the result not only of individual acts and characteristics, but also of law enforcement practices. A "predelinquent" youth might, therefore, be someone "on the verge of committing a criminal act," or "on the verge of getting caught and convicted for a criminal act." Second, even if there were consensus on the content of the category, there is no cmpirical data to support the notion that "predelinquency" status may accurately be predicted by techniques available in connection with ungovernability jurisdiction or by any other means. E. Schur, Radical Non-Intervention: Rethinking the Delinquencr Problem 46-51 (1973). Extensive retrospective analyses of high school and college students who had repeatedly disobeyed their parents during their younger years clearly demonstrate that these individuals seldom became delinquent and presently arc leading law-abiding lives. Iegal Action Support Project of the Bureau of Social Science Research, Research Memorandum on "Status Offenders," March 1972, at 22. And in a major recent test of the "predelinquency" predictive theory, psychiatrists and social workers attempted to predict which adolescents would become delinquents. The background factors on which the predictions were based were similar to those that are often important in ungovernability cases. The results clearly indicated an inability to predict accurately: The predictions were incorrect more than 50 percent of the time. E. Schur, supra, at 47.

140. Many sorts of behavior for which youths are brought to court as ungovernable are considered normal and healthy by child psychologists. For example, Goldstein, Freud and Solnit write that "revolt against any parental authority is normal developmentally since it is the adolescent's way towards establishing his own independent adult identity." Goldstein, supra note 22, at 34. See the discussion of intake allega. tions, supra note 33, and col. 1 of Appendix A infra. 
who are often competent enough to care for themselves. ${ }^{141}$ Furthermore, the failure to save a few unfortunate youths must be measured against the law's known and unavoidable negative consequences: the detention of youths in admittedly dangerous and deteriorated facilities for sorts of behavior that may be perfectly legal and sensible; the violation of the rights of youths who should be processed as delinquent and the isolation from available services of youths who should be processed as neglected; the illogical results of a court process vesting vast discretion in the hands of judges who are unable to exercise it without abuse; the increased intrafamily hostility that the process engenders in the short run; and the stigma sufered by youths as well as the negative attitude toward law and authority they develop in the long run. Juveniles should be "saved," of course, and "saving" them becomes an emotional issue whose lure no adult can easily ignore. But it is also important that the adolescents who in fact come before the court as allegedly ungovernable not be harmed'as documented in this Note; the cost of such harm far exceeds any benefit that would be lost as a consequence of abolition of the jurisdiction.

141. Of youths now processed under the ungovernability jurisdiction, 67 percent are over fourteen and 44 percent are over fifteen. See note 25 supra for a discussion of age. Many of the more serious allegations are even more highly concentrated among older youths. For example, at intake, 77 percent of the long runaway allegations concern youths over fourteen and 69 percent concern youths over fifteen. See note 41 supra. 


\section{APPENDIX A}

\begin{tabular}{|c|c|c|c|c|c|c|c|}
\hline Allegation & $\begin{array}{r}\text { Colum } \\
\text { Inta } \\
\text { Percent }\end{array}$ & & $\begin{array}{l}\text { Column 2:** } \\
\text { Referred To } \\
\text { Court } \\
\text { Percent }\end{array}$ & $\begin{array}{l}\text { Column } \\
\text { Petitior } \\
\text { Percent }\end{array}$ & (No.) & $\begin{array}{c}\text { Column 4:* * } \\
\text { Detained } \\
\text { Percent }\end{array}$ & $\begin{array}{l}\text { Adjudicated } \\
\text { Percent }\end{array}$ \\
\hline Refusal to Obey & 47 & (60) & 62 & 45 & (31) & 48 & 39 \\
\hline Truancy & 43 & (55) & 56 & 49 & (34) & 47 & 32 \\
\hline Late Hours & 36 & (46) & 59 & 30 & (21) & 38 & 38 \\
\hline $\begin{array}{l}\text { Staying out } \\
\text { Overnight }\end{array}$ & 19 & (25) & 56 & 28 & (19) & 47 & 42 \\
\hline $\begin{array}{l}\text { Short Runaway } \\
\text { Long Runaway }\end{array}$ & $\begin{array}{l}51 \\
13\end{array}$ & $\begin{array}{l}(66) \\
(17)\end{array}$ & $\begin{array}{l}64 \\
59\end{array}$ & $\begin{array}{l}45 \\
16\end{array}$ & $\begin{array}{l}\text { (31) } \\
\text { (11) }\end{array}$ & $\begin{array}{r}52 \\
9\end{array}$ & $\begin{array}{r}52 \\
9\end{array}$ \\
\hline Disorderly Conduct & $\mathbf{5}$ & ( 7$)$ & 71 & 10 & ( 7$)$ & 43 & 71 \\
\hline Vile Language & $\mathbf{5}$ & ( 7$)$ & 71 & 7 & (5) & 40 & 60 \\
\hline Verbal Abuse & 7 & (9) & 100 & 10 & ( 7$)$ & 57 & 71 \\
\hline $\begin{array}{l}\text { Undesirable } \\
\text { Companions }\end{array}$ & 14 & (18) & 44 & 16 & (11) & 55 & 27 \\
\hline Assault & 9 & (11) & 73 & 10 & $(7)$ & 14 & 43 \\
\hline Malicious Mischief & 2 & (3) & 100 & 6 & (4) & 25 & $\mathbf{0}$ \\
\hline Larceny & 5 & $(7)$ & 57 & 13 & (9) & 67 & 33 \\
\hline Shoplifting & 2 & (2) & 0 & 0 & $\Leftrightarrow$ & 一 & 一 \\
\hline Possession of Drugs & 23 & (30) & 67 & 15 & (10) & 40 & 20 \\
\hline $\begin{array}{l}\text { Possession of Drugs } \\
\text { to Sell }\end{array}$ & 2 & (3) & 67 & 2 & ( 1$)$ & 100 & 100 \\
\hline $\begin{array}{l}\text { Possession of } \\
\text { Alcohol }\end{array}$ & 4 & (5) & 80 & 4 & (3) & 100 & 33 \\
\hline $\begin{array}{l}\text { Possession of a } \\
\text { Dangerous Weapon }\end{array}$ & on 2 & (2) & $\mathbf{0}$ & $\mathbf{0}$ & $\leftrightarrow$ & 一 & - \\
\hline Arson & 3 & (4) & 50 & 2 & (1) & 100 & 100 \\
\hline Robbery & - & $\leftrightarrow$ & - & 2 & (1) & $\mathbf{0}$ & 0 \\
\hline Burglary & 1 & (1) & $\mathbf{0}$ & 0 & $(\rightarrow)$ & - & - \\
\hline Illegal Entry & 2 & (2) & 50 & 0 & $(-)$ & - & - \\
\hline Other & 21 & (27) & 56 & 13 & (9) & 56 & 44 \\
\hline $\begin{array}{r}\text { Undesirable } \\
\text { Boyfriend }\end{array}$ & $19^{\circ}$ & (25) & 64 & 10 & ( 7$)$ & 43 & 57 \\
\hline Prostitution & 1 & (1) & 100 & 2 & (1) & 0 & 0 \\
\hline Promiscuity & 4 & (5) & 80 & 6 & (4) & 50 & 50 \\
\hline Cohabitation & 1 & (1) & 100 & 2 & (1) & 0 & 0 \\
\hline $\begin{array}{l}\text { Spent Night } \\
\text { with Male }\end{array}$ & 2 & (3) & 100 & 2 & (1) & 0 & 0 \\
\hline $\begin{array}{l}\text { General Sexual } \\
\text { Misbehavior }\end{array}$ & 5 & (6) & 67 & 4 & (3) & 33 & 33 \\
\hline
\end{tabular}

- Columns 1 and 3 list the percent (and No.) of cases in which a particular allegation is made at INTAKE and PETITION, respectively.

** Columns 2, 4, and 5 list the percentage of cases in which a particular allegation was made that are REFERRED TO COURT. DETAINED, AND ADJUDICATED, respectively. 


\section{Ungovernability: The Unjustifiable Jurisdiction}

APPENDIX B

DISPOSITIONS (by percent)

Dep't

Private of Social

\begin{tabular}{|c|c|c|c|c|c|c|c|c|}
\hline $\begin{array}{c}\text { Petition } \\
\text { Allegations* }\end{array}$ & $\begin{array}{l}\text { With- } \\
\text { drawal }\end{array}$ & $\begin{array}{l}\text { Dis- } \\
\text { missal }\end{array}$ & $\begin{array}{c}\text { Proba- } \\
\text { tion }\end{array}$ & $\begin{array}{l}\text { Suspend- } \\
\text { ed Judg- } \\
\text { ment }\end{array}$ & $\begin{array}{l}\text { Agency } \\
\text { Place- } \\
\text { ment }\end{array}$ & $\begin{array}{c}\text { Services } \\
\text { Place- } \\
\text { ment }\end{array}$ & $\begin{array}{c}\text { Training } \\
\text { School }\end{array}$ & other \\
\hline Refusal to Obey & 36 & 30 & 4 & 11 & 11 & 4 & 4 & \\
\hline Truancy & 41 & 31 & 11 & 11 & 3 & 3 & & \\
\hline Late Hours & 23 & 47 & 12 & 6 & 6 & & & 6 \\
\hline Staying Out Overnight & 29 & $4 I$ & 18 & & 6 & G & & \\
\hline Short Runawayf & 39 & 21 & 14 & 7 & 11 & 4 & & \\
\hline Long Runaway & 50 & 50 & & & & & & \\
\hline Disorderly Conduct & & 43 & & 14 & 29 & & 14 & \\
\hline Vile Language & 25 & 25 & & & 50 & & & \\
\hline Verbal Abuse & & 49 & & 17 & 17 & & 17 & \\
\hline Undesirable Companions & 22 & 56 & 11 & & & & & 11 \\
\hline Assault & 60 & 20 & & & & & & 20 \\
\hline Malicious Mischicf & 50 & 50 & & & & & & \\
\hline Larceny & 37 & 37 & 13 & & 13 & & & \\
\hline Possession of Drugs & 29 & 57 & & & & & & 14 \\
\hline Possession of Drugs to Sell & & & & & 100 & & & \\
\hline Possession of Alcohol & & 67 & 33 & & & & & \\
\hline Arson & & & & & & & 100 & \\
\hline Other & 45 & 22 & 22 & & & & & 11 \\
\hline Undesirable Boyfriend & & 60 & 40 & & & & & \\
\hline Promiscuity & & 50 & 50 & & & & & \\
\hline Spent Night with Male & & 100 & & & & & & \\
\hline General Sexual Misbehavior & & 67 & 33 & & & & & \\
\hline
\end{tabular}

* The dispositions of some petition allegations (listed in column 3 of Appendix A) are not reported in this table because the cases had not reached dispositions at the time of this study.

$f$ Four percent of the short runaway allegations were disposed of by informal supervision. 